\title{
Sustainable IT: Challenges, Postures, and Outcomes
}

Edward Curry, National University of Ireland, Galway

\author{
Bill Guyon, Intel
}

Charles Sheridan, Intel Labs Europe

Brian Donnellan, National University of Ireland, Maynooth

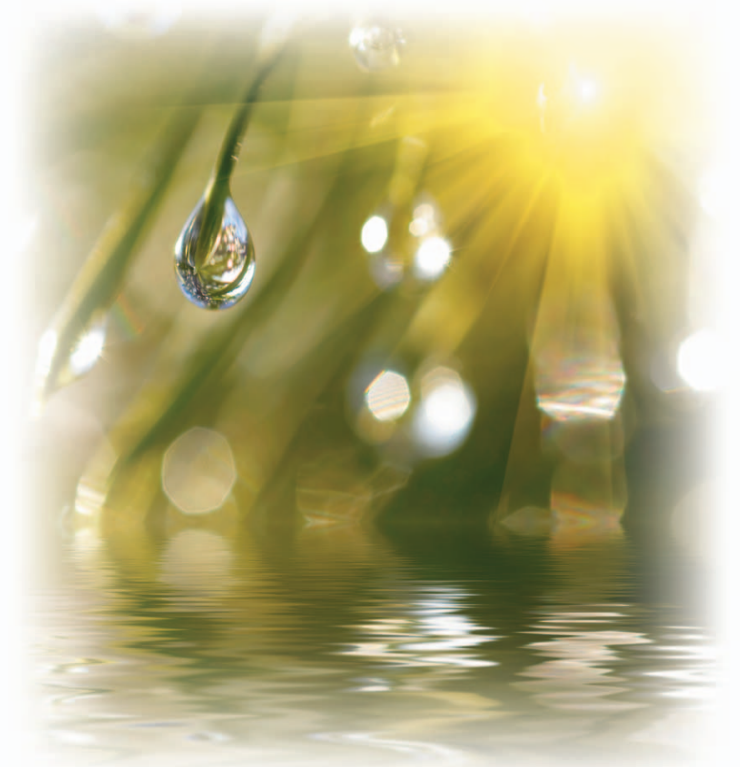

\section{Sustainable IT capabilities benefit not only the environment but also business value.}

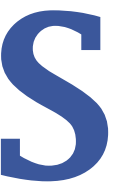

ustainability is an important business issue, affecting new products and services, compliance requirements, cost-reduction opportunities, reputation, and revenue generation. Many people think that incorporating sustainable practices requires a significant transformational program, but the ultimate goal is to embed sustainability into business-as-usual activities.

Researchers have estimated that information and communications technology (ICT) is responsible for at least 2 percent of global greenhouse gas emissions, with datacenters accounting for about 1.3 percent. In any individual business, ICT accounts for a much higher percentage of its carbon footprint.

Yet, researchers also estimate that ICT can reduce an organization's carbon footprint fivefold. To leverage these benefits, many corporate IT departments are now looking to develop sustainable IT capabilities. Unfortunately, these organizations often don't exploit IT's full potential in their efforts to achieve sustainability.

\section{SUSTAINABLE IT CHALLENGES}

Despite an increasing profile and tangible, measurable benefits, there remain numerous misconceptions about sustainable IT-that it's simply about saving the planet and isn't a business issue; that it's driven by compliance; that it only concerns energy savings, the datacenter, or what goes on in IT's own arena; and that it's expensive to implement.

Businesses considering sustainable IT face many questions:

- Does the organization recognize IT as a significant contributor to its overall sustainability strategy?

- How does IT contribute to the organization's sustainability goals?

- What more could IT do to contribute to those goals?

- Are there clear, measurable objectives for sustainable IT?

The issue is further complicated by the fact that sustainability is an enterprise-wide issue that spans the full value chain. The business already has challenges in developing clear business strategies, which might not fully address sustainable IT. This puts the onus on the IT department to deliver the benefits of sustainable IT across the organization.

\section{SUSTAINABLE IT FRAMEWORK}

Sustainability is still a relatively new, complex subject with few guidelines and best practices. Those responsible for achieving sustainable IT can feel like they are pioneers in uncharted territory with no map to guide them. This means that once they've reached certain milestones, it's unclear where they should go next and how far along the journey they are.

To address this issue, a consortium of leading organizations from industry, the nonprofit sector, and academia have developed a framework for improving sustainable IT capabilities (B. Donnellan, C. Sheridan, and E. Curry, "A Capability Maturity Framework for Sustainable Information and Communication Technology," IT Professional, vol. 13, no. 1, 2011, pp. 33-40). 


\begin{tabular}{|c|c|c|c|c|}
\hline Maturity & Cost Center & Service Center & Investment Center & Value Center \\
\hline Optimizing & $\begin{array}{l}\text { Continuous, } \\
\text { sustained IT } \\
\text { efficiencies }\end{array}$ & $\begin{array}{l}\text { Continuous } \\
\text { sustainable service } \\
\text { improvement }\end{array}$ & $\begin{array}{c}\text { Aligned to business } \\
\text { strategy, embeddedi } \\
\text { n portfolio }\end{array}$ & $\begin{array}{l}\text { Sustainability } \\
\text { opportunities } \\
\text { drive business } \\
\text { revenue }\end{array}$ \\
\hline Advanced & $\begin{array}{l}\text { Predictable } \\
\text { incremental } \\
\text { costsavings }\end{array}$ & $\begin{array}{l}\text { Regular, predictable } \\
\text { service enhancements }\end{array}$ & $\begin{array}{c}\text { Unmanaged, } \\
\text { unfunded, undefined } \\
\text { value }\end{array}$ & $\begin{array}{l}\text { Emerging } \\
\text { strategy, } \\
\text { repeatable impact } \\
\text { to the business }\end{array}$ \\
\hline Intermediate & $\begin{array}{l}\text { Defined objectives, } \\
\text { accountable } \\
\text { individuals }\end{array}$ & $\begin{array}{l}\text { Defined process to } \\
\text { meet business } \\
\text { sustainability needs }\end{array}$ & $\begin{array}{l}\text { Individual efforts, } \\
\text { limited recognition } \\
\text { of sustainability }\end{array}$ & $\begin{array}{l}\text { Cross-functional } \\
\text { capabilities to } \\
\text { dentify new } \\
\text { sustainability } \\
\text { opportunities }\end{array}$ \\
\hline Basic & $\begin{array}{l}\text { Cost savings driven } \\
\text { by tech upgrades }\end{array}$ & $\begin{array}{l}\text { Occasional service- } \\
\text { level sustainability } \\
\text { efficiency }\end{array}$ & $\begin{array}{l}\text { Driven by IT } \\
\text { strategy, projects } \\
\text { return predictable } \\
\text { sustainability } \\
\text { impacts }\end{array}$ & $\begin{array}{c}\text { Occasional } \\
\text { product } \\
\text { sustainability } \\
\text { improvements }\end{array}$ \\
\hline Initial & $\begin{array}{l}\text { Undefined cost } \\
\text { savings, limited }\end{array}$ & $\begin{array}{l}\text { Limited } \\
\text { sustainability in } \\
\text { service areas }\end{array}$ & $\begin{array}{l}\text { Defined governance, } \\
\text { new IT deployed with } \\
\text { defineds } \\
\text { ustainability output }\end{array}$ & $\begin{array}{c}\text { Limited } \\
\text { opportunities }\end{array}$ \\
\hline
\end{tabular}

Figure 1. The four basic IT postures at varying sustainable IT maturity levels.

This framework serves two important purposes. First, it's the basis of an assessment process that helps an organization determine the current maturity level of their sustainable IT efforts. Second, it provides a view of the growth path by identifying the next set of capabilities an organization should develop to drive greater business value from sustainable IT.

The framework defines a maturity curve with five levels-initial, basic, intermediate, advanced, and optimizing-for sustainable IT capabilities including strategy and planning, processes management, people and culture, and governance.

\section{IT POSTURES AND SUSTAINABILITY}

Sustainable IT goes beyond using IT to reduce energy consumption. It's also about helping the whole business meet its sustainability targets. This greatly extends IT's scope from simply executing the IT design-procure-run-dispose life cycle more efficiently to aligning business with IT and identifying those sustainability processes where IT can contribute.

When defining sustainable IT practices and capabilities, it's important to consider their potential value from the vantage point of different IT postures within the organization. There are four basic sustainable IT postures:

- the cost center manages the direct sustainability costs within the IT arena, with only indirect benefits for the business;

- the service center focuses on the sustainability of IT services supplied to support the business;

- the investment center delivers predictable sustainability benefits across both IT and the business; and

- the value center leverages sustainable IT as a strategic asset to drive sustainable business opportunities as a competitive differentiator.
Figure 1 compares these postures at the five sustainable IT maturity levels.

Regardless of its posture, IT can realize business value by maturing in the area of sustainable IT. However, IT's posture will determine the maximum achievable business value over time. For example, as long as IT's posture is a cost center, no matter how much it matures, it will always emphasize improving efficiencies. However, shifting to a service center posture could help IT get its foot into the business side of value. An effective sustainable IT program can help IT reposition itself from the viewpoint of both customers and management.

\section{SUSTAINABLE IT AT INTEL}

Intel has long recognized sustainability as a strategic priority for its company and has become a recognized leader in the space. At the beginning of 2008, CEO Paul Otellini set out an ambitious five-year plan to reduce environmental impacts in several areas, including energy, water, 
and reduction of carbon emissions by 20 percent on 2007 levels.

Seeing this as an opportunity for IT to play a key role in achieving the company's sustainability goals, $\mathrm{CIO}$ Diane Bryant established the IT Sustainability Program. The program used an investment posture to help the business deliver on its objectives by reducing the environmental impacts of IT operations, and to help transform the overall organization (E. Curry et al., "Developing a Sustainable IT Capability: Lessons From Intel's Journey," MIS Q. Executive, Jan. 2012, pp. 61-74).

One of the primary ways Intel IT reduced its carbon footprint was through server consolidation in its datacenters. While chip performance doubles every 18 months, the energy consumed by the chip does not double. Moore's law thus drives continuous chip-level energy efficiency, meaning that newer servers and laptops use less power than older machines to do the same work.

Intel IT has settled on a four-year server refresh policy, which has allowed it to double processing capacity and reduce costs. Together with an aggressive server virtualization strategy and improved management of workload distribution among servers, Intel IT has reduced the number of servers from 100,000 to 75,000 .

The program also helped the whole company to reduce its carbon footprint. In 2011, Intel had more than 91,500 employees across 164 sites in 62 countries. These employees would typically work in distributed and virtual teams. Intel IT made extensive use of collaboration technology to reduce the need for employees to travel. In 2010 and 2011, video conferencing efforts saved employees 435,000 travel hours - a cost savings of more than US\$114 million and an environmental savings of more than 87,500 metric tons of $\mathrm{CO}_{2}$ emissions.

By the end of 2011, Intel had reduced the carbon emissions of its IT operations by 60 percent compared to 2007. During the same time period, IT's computing processing capacity increased 159 percent, storage increased from 18.6 to 38.2 petabytes, and network bandwidth increased from 3.0 to 6.2 gigabits per secondall while delivering IT services to an additional 11,000 employees. Moreover, Intel's annual revenue rose by 41 percent.

I ntel IT's experience demonstrates that choosing an appropriate posture for sustainable IT, together with a structured methodology to maturing that capability, can deliver tangible financial and environmental savings, all while assisting businesses to meet their overall sustainability targets. [

Edward Curry is a research scientist at the Digital Enterprise Research Institute, National University of Ire- land, Galway. Contact him at edward. curry@deri.org.

Bill Guyon is a program manager at Intel's IT Sustainability Program Office.Contact him at bill.guyon@ intel.com.

Charles Sheridan is the associate director of Intel Labs Europe's Energy and Sustainability Research Lab. Contact him at charles.g.sheridan@intel. com.

Brian Donnellan is the academic director of the Innovative Value Institute, National University of Ireland, Maynooth. Contact him at brian. donnellan@nuim.ie.

Editor: Kirk W. Cameron, Dept. of Computer Science, Virginia Tech; greenit@computer.org

Selected CS articles and

columns are available for free at http://ComputingNow.computer.org.

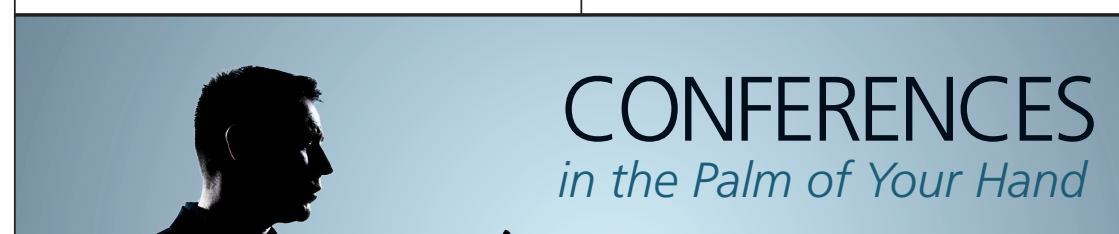

IEEE Computer Society's Conference Publishing Services (CPS) is now offering conference program mobile apps! Let your attendees have their conference schedule, conference information, and paper listings in the palm of their hands.

The conference program mobile app works for Android devices, iPhone, iPad, and the Kindle Fire.

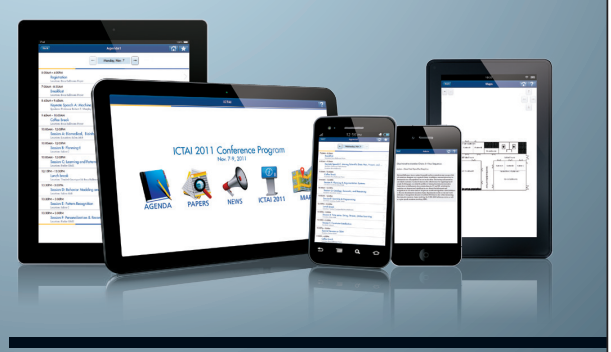

For more information please contact c

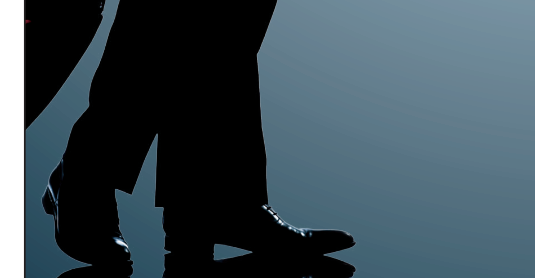

яні -

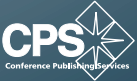

